\title{
A molecular contribution to the controversial taxonomical status of some freshwater snails (Caenogastropoda: Rissooidea, Cochliopidae) from the Central Andes desert to Patagonia
}

\author{
Eduardo Koch ${ }^{1,2}$, Stella M. Martin ${ }^{3}$ \& Nestor F. Ciocco ${ }^{1,2}$
}

\begin{abstract}
1. Instituto Argentino de Investigaciones de las Zonas Aridas (IADIZA), CCT-CONICET. Av. Ruiz Leal s/n, Parque General San Martín, Mendoza (5500), Argentina. (ekoch@mendoza-conicet.gob.ar; nciocco@mendoza-conicet.gob.ar)

2. Facultad de Ciencias Exactas y Naturales, Universidad Nacional de Cuyo. Av. Padre Contreras 1300, Mendoza (5500), Argentina

3. Comisión de Investigaciones Científicas, Buenos Aires Province (CIC), La Plata, Buenos Aires, Argentina. (smartin@fcnym.unlp.edu.ar)
\end{abstract}

\begin{abstract}
For over 40 years malacologists have been discussing the taxonomical status of Heleobia species, an enigmatic genus from Cochliopidae family (Caenogastropoda: Rissooidea). As with other rissooidean families, the considerable character convergence and the paucity of anatomical synapomorphies has proved to be a problem in resolving cochliopid phylogenetic relations and establishing the validity of several nominal cochliopid species. Here we present a molecular contribution to solve the taxonomical status of one of the most abundant Southern South America cochliopid genera which has many endemic species. We report molecular evidence that supports three of the four Heleobia groups described for this region, the "australis", "parchappii" and "piscium" groups. The fourth, the "hatcheri" group, belongs not to Heleobia but to a different genus which itself should not be considered as part of the family Cochliopidae but closely related to genus Potamolithus Pilsbry \& Rush, 1896.
\end{abstract}

KEYWORDS. Cochliopidae, Heleobia, taxonomical status, Arid diagonal, South America.

\begin{abstract}
RESUMEN. Una contribución molecular al controvertido estatus taxonómico de un grupo de caracoles dulceacuícolas (Caenogastropoda: Rissooidea, Cochliopidae) distribuídos desde el desierto de los Andes centrales hasta la Patagonia. Durante más de 40 años se ha discutido el estatus taxonómico de diversas especies del enigmático género Heleobia de la Familia Cochliopidae (Caenogastropoda: Rissooidea). Como sucede con otras familias de rissooideos, la abundancia de caracteres convergentes y la escasez de sinapomorfías anatómicas han representado un problema para resolver las relaciones filogenéticas de Cochliopidae y definir la validez de varias de las especies nominales de esta Familia. Presentamos aquí una contribución molecular tendiente a resolver el estatus taxonómico de uno de los más abundantes géneros de la porción meridional de Sudamérica que incluye varias especies endémicas. Nuestra evidencia molecular reconfirma tres de los cuatro grupos de Heleobia en los que se han agrupado las especies del género en esta región: "australis", "parchappii" y "piscium". El cuarto, el grupo "hatcheri", no pertenece a Heleobia sino a un género diferente que no debería ser considerado como integrante de la Familia Cochliopidae, sino estrechamente relacionado al género Potamolithus Pilsbry y Rush, 1896.
\end{abstract}

PALABRAS CLAVE. Cochliopidae, Heleobia, estatus taxonómico, Diagonal Árida, Sudamérica.

Cochliopidae is a family of rissooidean snails composed of more than 30 genera and more than 260 species that mainly inhabit freshwaters in tropical and temperate regions of America and several regions of Eurasia (HERShler \& THOMPSON, 1992). The status of this enigmatic family remained unstable during many years, until WILKE et al. (2001), using molecular tools, confirmed that Cochliopidae is a family distinct from Hydrobiidae as it is accepted by BOUCHET \& ROCROI (2005). The monophyly of the family, the consistency of molecular and anatomical characters (mainly closed spermathecal duct and oviduct jointed directly to the albumen gland), and its phylogenetic relationships have been assessed and discussed by Liv et al., 2001 (as Cochliopinae) and WILKE et al. (2001) who mainly utilized DNA sequences of mitochondrial genes. Previous attempts to resolve systematic and/or phylogeny of Hydrobiids based only on morphological data (e.g. Kabat \& Hershler, 1993; Falniowsky \& Szarowska, 2000) poorly resolved the uncertainty due to considerable character convergence and the scarcity of anatomical synapomorphies.

Cochliopidae are abundant snails worldwide. However, sequenced taxa from South America are underrepresented, as was pointed out by Liv et al. (2001) discussing biogeography. Recent molecular characterization of endemic gastropod fauna from Titicaca Lake (KROLL et al., 2012) and Northern of Chile (Collado et al., 2013) appear to be the only available cochliopid information for this subcontinent.

The Argentinian Cochliopidae were studied originally by M. C. Gaillard (unpublished data) and Gaillard \& CAstellanos (1976) both as family Hydrobiidae and genus Littoridina. They listed 18 nominal species, gathered in 4 groups ("australis": South Atlantic littoral waters; "piscium": subtropical freshwaters; "parchappei": Pampean region, North Patagonia and Centre-West of Argentina; "hatcheri": Patagonian continental region) using morphological characters of the shell, operculum, radula and penis. A compilation of gastropod snails from the freshwater of Argentina (Rumi et al., 2008) reported 16 species of Cochliopidae (all belonging to the genus Heleobia and 10 of them endemics). A review of the taxonomy of Heleobia with emphasis on Argentina was reported by CAZZANiga (2011); none of these previous studies for the Argentinian cochliopidae species included molecular data with the exception of Kroll et al. (2012), where two 
sequences of Heleobia are mentioned, both collected from Laguna Mar Chiquita by C. G. de Francesco and identified by R. Hershler (Museum records) as $H$. australis and $H$. parchappii (both preserved in the Smithsonian Natural History Museum).

The Centre-West of Argentina, extending between $28^{\circ}$ and $37^{\circ} \mathrm{S}$ and $65^{\circ}$ and $71^{\circ} \mathrm{W}$, lies within the dominion of the South American Arid Diagonal, which is considered to have been climatically sensitive to the latitudinal shift of the Pacific and Atlantic anticyclone centers during the late Pleistocene and the Holocene (ABraham de VAZquez et al., 2000). The dominant climate is semiarid with a mean annual rainfall of $250 \mathrm{~mm}$ in the eastern foothills of the Andes (CAPITANELli, 2005). With respect to freshwater gastropods, this region constitutes the 'Cuyo Malacological Province' (CMP) (NúÑEZ et al., 2010) and covers approximately $280,000 \mathrm{~km}^{2}$. The gastropod diversity of this region is one of the lowest in the country and comprises only 18 known species spread over the families Ampullariidae (1 species), Cochliopidae (5), Physidae (4), Planorbidae (2), Lymnaeidae (2), and Chilinidae (4) (NúÑEz et al., 2010; GutiérRez GREGORIC et al., 2014). Despite this low biodiversity, the cochliopid species from the CMP are interesting issue due to their confused taxonomical status. The five Cochliopidae species originally described for the CMP belong to the genus Heleobia; one included in the "hatcheri group" H. hatcheri (Pilsbry, 1911) and four in the "parchappii group": H. parchappii (d'Orbigny, 1835), $H$. kuesteri (Strobel, 1874), H. occidentalis (Doering, 1885), and $H$. vianai (Parodiz, 1960). According to CAzZaniga (1980), this last name is a synonym of $H$. occidentalis (as Littoridina occidentalis). GaIllard \& CASTELlanos (1976) proposed H. occidentalis as a geographical variation of $H$. parchappii for saline waters, while CAzZANIGA (1980) considered $H$. occidentalis a valid species after examining penis morphology. De Francesco (2007) suggested $H$. occidentalis as synonym of $H$. parchappii based on conchological characters, criteria adopted in recent ecological studies in saline areas from the CMP by CiocCO \& Scheibler (2008) and De Francesco \& Hassan (2009).

Heleobia kuesteri also remain enigmatic. Based on geographic distribution and the original conchological description of Strobel, M. C. Gaillard (unpublished data) considered this species within the "parchappii group". CAZZANiga (1981) proposed H. kuesteri as species inquirenda and Ciocco (2011) suggested that it could be a valid taxon related to the "parchappii group".

Heleobia hatcheri, abundant in Patagonian waters, differs from the other Heleobia species from the CMP in, among other characters, the presence of a so called nuchal papilla in all females studied (pseudohermaphroditism or natural imposex, MARTín, 2002), the only reported sex in CMP populations where sex ratios have been studied (Uspallata River; MARTín, 2002; CiocCO, 2011). This organ was previously mistakenly interpreted as a reduced and functional penis from hypothetical $H$. hatcheri males (Gaillard \& Castellanos, 1976; Cazzaniga, 1981), to the point that a new genus was proposed (Strobeliella; Cazzaniga, 1981).

Additionally, a new morphotype with similar shell features to $H$. hatcheri (ovate-conic shell), but discontinuous peristome, was recently found in several localities of the CMP (Heleobia sp.; Ciocco \& Koch, unpublished data).

The goal of this study is to develop a molecular approach to solve the taxonomical status of Heleobia species from the Centre-West of Argentina as a first step towards an integrated phylogenetic study of the Southern South America cochliopids. Considering: i) the proteincoding mitochondrial citocrome oxidase I (COI) gene does not show insertions or deletions in the superfamily Rissooidea; ii) the vast information on COI gene sequence available in NCBI GeneBank for the Gastropoda in general and iii) that this sequence shows good phylogenetic signals from population to family levels (WILKE et al., 2001), we analyze COI sequences from 7 taxa (5 cochliopid and 2 non cochliopid ones) without previous data in GenBank, in an attempt to provide new considerations tending to solve a long term controversial issue.

\section{MATERIALS AND METHODS}

Specimens. Individuals from CMP were collected in Aguas Negras ( $30^{\circ} 18^{\prime} 6.72^{\prime \prime}$ S, 68 $68^{\circ} 43^{\prime} 46.62^{\prime \prime}$ W, San Juan Province), Uspallata stream ( $32^{\circ} 40^{\prime} 11.1^{\prime \prime} \mathrm{S}, 69^{\circ} 21^{\prime} 52.8^{\prime \prime} \mathrm{W}$, Mendoza Province), and Laguna Bebedero (33⒊'S, $66^{\circ} 34^{\prime} \mathrm{W}$, San Luis Province) during expeditions to the CMP between 2011 and 2013. Heleobia piscium (d'Orbigny, 1835) and Potamolithus spp. specimens were collected in 2014 from Martin Garcia Island, upper portion from de la Plata River basin $\left(34^{\circ} 11^{\prime} \mathrm{S}, 58^{\circ} 15^{\prime} \mathrm{W}\right.$, Buenos Aires Province). In all cases, animals were alcohol preserved following previous menthol relaxation. Voucher specimens for all studied taxa were deposited in the Museo de La Plata collection under voucher numbers: MLP MA 13806 to 13812 .

DNA isolation, PCR and sequencing. The total DNA was extracted from the foot of dissected snails. Tissues were rinsed in TE buffer (10mM Tris $1 \mathrm{mM}$ EDTA, $\mathrm{pH} 8)$ and digested overnight in CTAB (Cetyl trimethylammonium bromide) buffer containing proteinase $\mathrm{K}(0.14 \mathrm{mg}$ at $60^{\circ} \mathrm{C}$ ) and 2-Mercaptoethanol. DNA was purified by a threefold extraction with chloroform-isoamyl alcohol (24:1) followed by precipitation with ethanol. The DNA was then resuspended in DNAse/RNAse free distilled water. A 655bp fragment of the COI gene was amplified by means of the primers of FolmER et al. (1994). Amplification by the polymerase chain reaction (PCR) was performed in a final volume of $50 \mu \mathrm{l}$ containing: $50-100 \mathrm{ng}$ of template DNA, $0.1 \mu \mathrm{M}$ of each primer, $1 \mathrm{X}$ PCR buffer, $50 \mu \mathrm{M}$ dNTPs, 2.5 $\mathrm{mM} \mathrm{MgCl}$, and $1 \mathrm{U}$ Taq polymerase (Invitrogen, Brazil). The thermocycling sequence was conducted at $94^{\circ} \mathrm{C}$ for $3 \mathrm{~min}$; with 5 cycles at $94^{\circ} \mathrm{C}$ for $30 \mathrm{~s}, 42^{\circ} \mathrm{C}$ for $30 \mathrm{~s}$, and $72^{\circ} \mathrm{C}$ for $1 \mathrm{~min} 30 \mathrm{~s}$; followed by 34 cycles at $94^{\circ} \mathrm{C}$ for 30 $\mathrm{s}, 45^{\circ} \mathrm{C}$ for $30 \mathrm{~s}$, and $72^{\circ} \mathrm{C}$ for $1 \mathrm{~min} 30 \mathrm{~s}$; with a final chain 
extension at $72^{\circ} \mathrm{C}$ for $5 \mathrm{~min} .5 \mu \mathrm{l}$ of each PCR product was tested on a $1 \%(\mathrm{w} / \mathrm{v})$ agarose gel electrophoresis. The remainders $(45 \mu \mathrm{L})$ of reactions with the expected PCR product were purified with AccuPrep® PCR purification Kit (Bioneer Corporation, Korea), then sequenced in both directions (Instituto de Biotecnología, Unidad de Genómica, INTA Castelar, Argentina). The resulting sequences were analyzed with BioEdit (HALL, 1999) to obtain consensus sequences for each individual.

Sequence alignment. The COI sequences were unambiguously aligned in MEGA6 (TAMURA et al., 2013) and trimmed to a total length of 638bp. Phylogenetic analysis was undertaken comparing gene sequences from this study and related sequences in GenBank (Tab. I). A phylogenetic tree was constructed using the Maximum Likelihood method based on the Tamura-Nei model (Tamura \& NeI, 1993). The bootstrap consensus tree inferred from 1000 replicates is taken to represent the evolutionary history of the taxa analyzed (FeLSENSTEIN, 1985). Branches corresponding to partitions reproduced in less than $50 \%$ of the bootstrap replicates are collapsed.
The initial tree for the heuristic search was obtained automatically by applying Neighbor-Join and BioNJ algorithms to a matrix of pairwise distances estimated using the Maximum Composite Likelihood (MCL) approach, and then selecting the topology with the best log likelihood value. The analysis involved 38 nucleotide sequences. All codon positions were included. All positions containing gaps and missing data were eliminated. There were a total of 636 positions in the final dataset. Evolutionary analyses were conducted in MEGA6 (TAMURA et al., 2013).

\section{RESULTS}

The bootstrap consensus tree yielded from the ML analysis comprises the outgroup taxon Pomatiopsis lapidaria (Say, 1817), 4 dominant clades and several subclades (from top to bottom; Fig 1.):

1. Clade Cochliopidae was represented by 4 genera (Heleobia, Semisalsa, Heleobops and Tryonia), 3 subclades and 4 lineages:

Tab. I. Taxon, collection locality data, reference and GenBank accession numbers for specimens analyzed in this study.

\begin{tabular}{|c|c|c|c|}
\hline Taxon & Locality & Reference & GenBank accession number \\
\hline Benedictia baicalensis & Lake Baika, Russia & WILKE et al., 2013 & HQ623171 \\
\hline Heleobia andicola andicola & Patapatini Island, Lake Titicaca, Bolivia & Kroll et al., 2012 & JQ973028 \\
\hline Heleobia andicola culminea (Peru) & Umayo Island, Lake Umayo, Peru & KROLL et al., 2012 & JQ973034 \\
\hline Heleobia andicola culminea (Bolivia) & Huarina, Lake Titicaca, Bolivia & KROLl et al., 2012 & JQ973030 \\
\hline Heleobia andicola nеveui & Vilque Chico, Lake Titicaca, Peru & KROLL et al., 2012 & JQ973035 \\
\hline Heleobia aperta & Chua, Lake Titicaca, Bolivia & Kroll et al., 2012 & JQ973036 \\
\hline Heleobia australis & Mar Chiquita, Argentina & KROLL et al., 2012 & JQ972708 \\
\hline Heleobia hatcheri & Aguas Negras, San Juan. Argentina & this study & KM220905 \\
\hline Heleobia kuesteri & Uspallata & this study & KM220904 \\
\hline Heleobia languiensis & Lake Langui Layo, Peru & KROLL et al., 2012 & JQ973042 \\
\hline Heleobia limariensis & Huasco River, Vallenar Chile & KROLL et al., 2012 & JQ973043 \\
\hline Heleobia loaensis & Loa River, Quillagua Chila & Kroll et al., 2012 & JQ973044 \\
\hline Heleobia mirum & Ajilata, Lake Titicaca, Bolivia & KROLL et al., 2012 & JQ973046 \\
\hline Heleobia occidentalis & Laguna Bededro, San Luis Argentina & this study & KM220907 \\
\hline Heleobia ortoni & Chucuito, Lake Titicaca, Peru & Kroll et al., 2012 & JQ973049 \\
\hline Heleobia parchappii & Mar Chiquita, Argentina & KROLL et al., 2012 & JQ972709 \\
\hline Heleobia piscium & Isla Martín Garcia & this study & KM220906 \\
\hline Heleobia poopoensis & Laca Jahuira River, Bolivia & Kroll et al., 2012 & JQ973050 \\
\hline Heleobia saracochae & Lake Saracocha, Peru & KROLL et al., 2012 & JQ973051 \\
\hline Heleobia sp. & Uspallata & this study & KM220908 \\
\hline Heleobia umbiculata & Sol Island, Lake Titicaca, Bolivia & Kroll et al., 2012 & JQ973053 \\
\hline Heleobops carrikeri & Oyster Pond, Falmouth, USA & Kroll et al., 2012 & JQ973019 \\
\hline Hydrobia acuta acuta & Etang du Prévost, Hérault, France & WILKE et al., 2000 & AF278808 \\
\hline Hydrobia acuta neglecta & & DAVIS et al., 1998 & AF253079 \\
\hline Leptopyrgus tainui & Kawhia, New Zeland & HAASE, 2005 & AY631078 \\
\hline Lithoglyphus naticoides & Narew River, Poland & WiLKE et al., 2001 & AF367642 \\
\hline Meridiopyrgus murihiku & Browns, New Zeland & HAASE, 2005 & AY631084 \\
\hline Opacuincola permutata & Inangahua, New Zeland & HAASE, 2005 & AY631100 \\
\hline Pomatiopsis lapidaria (outgroup) & Cruger Island, Hudson River, USA & Liu et al., 2001 & AF354774 \\
\hline Potamolithus agapetus & Isla Martín Garcia & this study & KM220910 \\
\hline Potamolithus buschii & Isla Martín Garcia & this study & KM220909 \\
\hline Potamolithus ribeirensis & Iporanga River, Sao Paulo, Brazil & WILKE et al., 2013 & JX970618 \\
\hline Potamopyrgus antipodarum & New Zeland & NEIMAN et al., 2010 & GQ996429 \\
\hline Semisalsa dalamatica & Pirovac Spring, Croatia & WILKE et al., 2001 & AF367631 \\
\hline Semisalsa foxianensis & $\begin{array}{l}\text { Thermal Springs, Torretta, Montecatini Terme, } \\
\text { Italy }\end{array}$ & KROLL et al., 2012 & JQ973023 \\
\hline Semisalsa scamandri & Étang du Charnier, Saint Gilles, France & KROLL et al., 2012 & JQ973025 \\
\hline Semisalsa stagnorum & Kaaskenswaters, Zierikzee, The Netherlands & Kroll et al., 2012 & JQ973024 \\
\hline Tryonia imitator & Peñasquitos Lagoon, California, USA & HERSHLER et al., 1999 & AF061769 \\
\hline
\end{tabular}



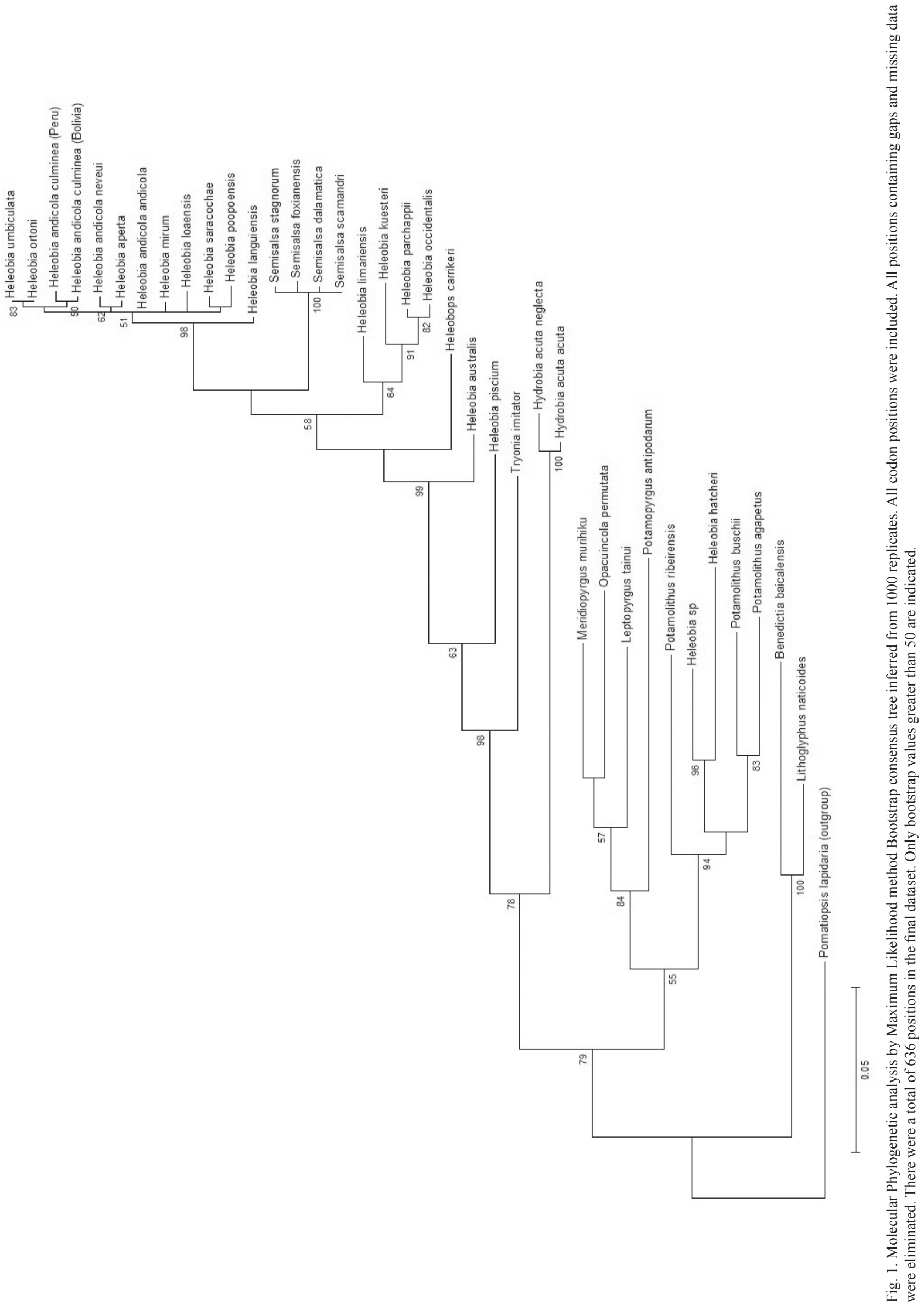
1.1. An Altiplano Lakes subclade containing 11 species and subspecies of Heleobia genus;

1.2. An european Semisalsa species subclade including 4 taxa;

1.3. A subclade containing 4 Heleobia spp.

Four basal lineages [Heleobops carrikeri (Davies and McKee, 1989), Heleobia australis, Heleobia piscium and Tryonia imitator (Pilsbry, 1899)] not belonging to Subclades 1.1- 1.3.

2. Clade Hydrobiidae represented by 2 species of the genus Hydrobia

3. Clade Tateidae containing the genera Meridyopirgus, Opacuincola, Leptopyrgus, Potamopyrgus and Heleobia, grouped in two subclades:

3.1. With Meridyopirgus, Opacuincola, Leptopyrgus, Potamopyrgus.

3.2. Containing 3 species of Potamolithus, Heleobia hatcheri and morphotype Heleobia sp.

4. Clade Litoglyphidae with Benedicta and Lithoglyphus genera.

Three of the Heleobia spp. from Subclade 1.3 correspond to taxa recorded from the CMP: $H$. parchappii, $H$. occidentalis and H. kuesteri. The topology of this subclade showed that two first species are very close, reinforcing that $H$. occidentalis is synonym of $H$. parchappii. Also, analysis of this subclade confirmed that Heleobia kuesteri belongs to "parchappii group" and suggested that it should be accepted as a valid species. Heleobia limariensis, from Huasco River Basin from northern Chile and the three CMP species of this subclade, share an arid Andean environment.

The four basal lineages of Cochliopidae (Heleobops carrikeri, Heleobia australis, Heleobia piscium and Tryonia imitator) correspond to saline or euryhaline taxa.

Heleobia hatcheri (and the very similar morphotype Heleobia sp.) from CMP, resolved outside Cochliopidae. Both were integrated in the well-defined Tateidae subclade 3.2 composed of 3 Potamolithus species: P. agapetus (Pilsbry, 1911) and P. buschii (Fraunfeld, 1865), sympatric taxa from de la Plata River, and P. ribeirensis (Pilsbry, 1911, sensu Davis \& Pons Da Silva, 1984), from Iporanga River, Southern Brazil, part of the Paraná and La Plata River drainage systems. "Heleobia hatcheri" and "Heleobia sp." were closely-related to the three Potamolithus species studied in this work and these three taxa are more closely linked to Tateidae family than to Lythoglyphidae, as was pointed out by WILKE et al. (2013) for P. ribeirensis.

\section{DISCUSSION}

Our results suggest that only two Cochliopidae species of the "parchappii group" should be recognized in the Centre-West of Argentina: H. parchappii and H. kuesteri. Heleobia parchappii is a elongate-conic shell species abundant in oligohaline waters from the Pampean Region, able to develop populations in estuaries (DE FRANCESCO \& IsLA 2004) or in hard continental waters such as those of Desaguadero, Llancanelo and Bebebero saline's from the CMP (Ciocco \& Scheibler, 2008; De Francesco \& Hassan, 2009, and this work). Heleobia vianai (cited from only one CMP locality, M. C. Gaillard, unpublished data) and $\mathrm{H}$. occidentalis from Bebedero and Llancanelo saline areas, should be considered as synonymus of $H$. parchappii as was suggested by CAZZANiGa (1980) and De Francesco (2007), respectively. We were unable to obtain COI sequences for preserved $H$. vianai material studied (Lote MLP 9224 Invertebrates Collection of Museo de La Plata, Argentina), or collect any H. vianai specimen from the same area as the type locality where saline waters are predominant. CAZZANIGA (1980), based in penial morphology, did not detect significant differences between $H$. vianai and $H$. occidentalis, and proposed that the former is a synonym of $H$. occidentalis which, according to the COI sequences studied in this work, should itself be considered as a synonym of $H$. parchappii.

Heleobia kuesteri, meanwhile, is an elongate-conic shell endemic species from the Centre-West of Argentina abundant in relatively soft waters of the subandean foothills of the CMP. Despite this species needs to be redescribed including soft parts. The shell features of the scarce available material in malacological collections identified as H. kuesteri (Lote 20997/1 Invertebrates Collection of Museo Argentino de Ciencias Naturales Bernardino Rivadavia, Buenos Aires, Argentina) appear identical to the numerous specimens we collected in the Centre and North of the CMP. Although shell morphology of this species is different from typical $H$. parchappii, De FranCESCO \& Hassan (2009) cited for the South of the CMP another abundant batch of individuals, with identical conchological features to those we found in the Centre and North of the CMP, as Heleobia aff. parchappii based on similarity of penial complex. However, these authors recognized difficulties in identifying this material and considered the possibility that it could be an undescribed species or $H$. kuesteri.

Preliminary studies using scanning electron microscopy (SEM) performed on shell, penis and radula of many Cochliopidae from Argentina indicated that i) the radulae of $H$. parchappii and $H$. kuesteri are similar, ii) although both species penial complexes are similar, there are small differences in the shape and the porosity porous of the papillae, and distal end shape, iii) the whorls of $H$. kuesteri are less convex than those of H. parchappii, supporting the possibility that they are different species. The COI sequences analyzed here seemed to reinforce this possibility. However, more detailed anatomical studies, including female genitalia and use of other molecular markers are necessary to solve the question definitively.

Our molecular results would validate the "australis" and "piscium" groups. H. australis is an elongated-conic shell species of marine and littoral waters that, along with Tryonia imitator and Heleobeops carrikeri (both from hard USA waters; HershLER et al., 1999 and WiLKe et al., 2000, respectively) shares with $H$. piscium (an oligo- to euryhaline species) its condition of basal linage of the subclades 
from clade Cochliopidae (i.e. Altiplano Lakes, European Semisalsa and CMP Heleobia spp.; Fig.1 tree). Besides COI sequences differences reported in this work and differences in penis morphology and shell form (elongate-conic in $H$. australis and conic in H. piscium; GaILlard \& CASTELlanos, 1976), both species differs in development mode: indirect in H. australis (MARcus \& Marcus, 1963, 1965; Neves et al., 2010) and direct in H. piscium (Stella M. Martin, pers. observ.).

Our results suggest that Heleobia hatcheri and the morphologically similar Heleobia sp. should not be included among the family Cochliopidae, and that they would be closely-related to the three studied Potamolithus species. The latter has two novel and significant implications: i) the conspicuous group "hatcheri". traditional component of the Cochliopidae from Chile (BIESE, 1944) and Argentina (Gaillard \& Castellanos, 1976), would disappear as part of this family; ii) as was recently suggested by WILKE et al. (2013), the Potamolithus genus endemic from South America would not be Lithoglyphidae as was proposed originally by Davis \& Pons DA SiLVA (1984).

Several other morphological features of $H$. hatcheri in addition to its ovate-conic and small shells have previously suggested that this taxon departs from typical cochliopid characters. These include the absence of a penis and the parthenogenetic (and pseudohermaphroditic) condition of the species shown by MARTín (2002). This reproductive mode is infrequent in Cochliopidae. Moreover, unlike other parthenogenetic rissooideans such as Potamopyrgus, H. hatcheri is oviparous (CAZZANIGA, 2011). Although mistaken, the original interpretation of the species nuchal papillae as a reduced penis, also suggested that $H$. hatcheri was different from the remaining Cochliopidae, to the point that a new genus (Strobeliella) was proposed for $H$. hatcheri (CAZZANIGA, 1981). In the same sense, the two or three cusps present in the basis of rachidean teeth of $H$. hatcheri radula are absent in all other Cochliopidae from the southern end of South American (CAZZANigA, 2011). Although Hershler \& THOMPSON (1992) maintained the synonymy of Strobeliella with Heleobia, assuming that the new proposed genus was based on gerontic specimens having a degenerate penis, our molecular data reinstate the requirement for a distinct generic name for $H$. hatcheri.

Interestingly, there is no fossil record of $H$. hatcheri from the Centre-West of Argentina although the Holocene aquatic malacofauna of the region is, with the exception of this species and the exotic Physa acuta Draparnaud, 1805, identical to the current gastropod and bivalve assemblages (De Francesco \& Hassan, 2009). These observations suggest that this enigmatic taxon may have colonized the Centre-West of Argentina in the last $c a$. 11,000 years.

Heleobia sp., as previously mentioned, must undoubtedly be considered as very close to $H$. hatcheri, a taxon with which it shares in sympatry the relatively soft waters of the CMP. Morphological studies indicate that the species have an identical radula, similar pigmentation in the prosboscis and tentacles together with nuchal papillae and absence of males in all the examined populations. The only notable difference from $H$. hatcheri is that the Heleobia sp. shell has a discontinuous peristome, a character that could be interpreted as an intraspecific variation, as also appears to be the case in H. kuesteri. Nevertheless, a detailed morphological description of this morphotype and the eventual incorporation of other molecular markers should be taken into account before considering it as a new species or a $H$. hatcheri variation.

With respect to the phylogenetic proximity of $H$. hatcheri to the South American genus Potamolithus and the suggestion that the latter belong not to Lithoglyphidae but to Tateidae (WILKE et al., 2013), these authors indicated that "We do not know of any unique characters defining this group". Nevertheless, the diagnosis of the PalearticNeartic Lithoglyphidae is made by the closed ventral wall of the female capsule gland and the blade-like penis lacking large appendages and specialized glands, remarking finally that the genus Potamolithus was resolved as a member of the Tateidae Clade in all their molecular analysis (WILKE et al., 2013).

The Potamolithus species incorporated in this study, P. buschii and P. agapetus, are sympatric in the La Plata River basin. Potamolithus agapetus presents a marked secondary sexual dimorphism on shell shape and size (López Armengol, 1996). Females of both taxa show a nuchal node on the right side of the neck as was described by Davis \& Pons Da Silva (1984) for P. ribeirensis. This fleshy protuberance is situated where the base of the simple, and without appendages, penis is located (DAVIS \& Pons DA Silva, 1984; López ARMEnGol, 1996) in the three mentioned Potamolithus species, also coinciding with the position of the nuchal papilla of the parthenogenetic $H$. hatcheri females (MARTín, 2002). Unfortunately, the female genitalia of $P$. buschii and $P$. agapetus have not been described.

The only description of female genitalia available for the genus corresponds to that of P. ribeirensis (DAVIS \& Pons DA Silva, 1984). While it has served as the basis to define the "typical" idealized anatomical ground plan of the Lithoglyphidae (WILKE et al., 2001), it is not incompatible with the characterization of the Tateidae female genitalia as "simple, usually with one distal seminal receptacle and a bursa copulatrix; ventral channel occasionally separated to form a vestibule", (WILKE et al., 2013). In H. hatcheri the spermathecal tube seems not be separated from the albumen gland, which would distinguish it from the Cochliopidae. However a deeper anatomical study of $H$. hatcheri, with emphasis on the female genitalia, and the incorporation of other mitochondrial markers is necessary to determine the genus and, more importantly, the family to which $H$. hatcheri belongs.

Acknowledgements. This study was financially supported by CONICET (PIP-0398) and SECTyP-UNCuyo (Proy. 06/M037 and Proy. 06/M046). 


\section{REFERENCES}

Abraham de Vazquez, E.; Garleff, K.; Liebricht, H.; Reigaraz, A.; Schäbitz, F.; Squeo, F.; Stingl, H.; Veit, H. \& Villagran, C. 2000. Geomorphology and paleoecology of the arid diagonal in southern South America. In: Miller, H. \& Hervé, F. eds. Geodesy, Geomorphology and Soil Science. Sonderheft, ZAG, p. 55-61.

BIESE, W. A. 1944. Revisión de los moluscos terrestres y de agua dulce provistos de concha de Chile. Parte I, Familia Amnicolidae. Boletín del Museo de Historia Natural, Chile 22:169-190.

Bouchet, P. \& Rocroi, J. P. 2005. Classification and nomenclator of gastropod families. Malacologia 47(1/2):1-397.

Capitanelli, R. G. 2005. Climatología de Mendoza. Mendoza, Editorial de la Facultad de Filosofía y Letras de la Universidad Nacional de Cuyo.

Cazzaniga, N. J. 1980. Notas sobre hidróbidos argentinos (Gastropoda Rissoidea). I. Acerca de Littoridina occidentalis (Doering, 1884). Neotropica 26(76):187-191.

. 1981. Notas sobre hidróbidos argentinos (Gastropoda Rissoidea). Strobeliella, un nuevo género de la Patagonia. Neotropica 27(77):310 .

2011. Heleobia Stimpson, 1865: Taxonomía. In: CAzzaniga, N. J. ed. El género Heleobia (Caenogastropoda: Cochliopidae) en América del Sur. Amici Molluscarum (número especial):12-17.

Ciocco, N. F. 2011. Diversidad, biología y ecología de especies del género Heleobia de la Provincia Malacológica de Cuyo, Argentina. In: Cazzaniga, N. J. ed. El género Heleobia (Caenogastropoda: Cochliopidae) en América del Sur. Amici Molluscarum (número especial):20-22.

Ciocco, N. F. \& Scheibler, E. E. 2008. Malacofauna of the littoral benthos of a saline lake in southern Mendoza, Argentina. Fundamental and Applied Limnology 172(2):87-98.

Collado, G. A.; Valladares, M. A. \& Méndez, M. A. 2013. Hidden diversity in spring snails from the Andean Altiplano, the second highest plateau on Earth, and the Atacama Desert, the driest place in the world. Zoological Studies 52:1-13.

Davis, G. M. \& Pons da Silva, M. C. P. 1984. Potamolithus: morphology, convergence, and relationships among hydrobioid snails. Malacologia 25(1):73-108.

De Francesco, C. G. 2007. Las limitaciones a la identificación de especies de Heleobia Stimpson, 1856 (Gastropoda, Rissooidea) en el registro fósil del Cuaternario Tardío sus implicancias paleoambientales. Ameghiniana 44(3):631-635.

De Francesco, C. G. \& Hassan, G. S. 2009. The significance of molluscs as paleoecological indicators of freshwater systems in central-western Argentina. Palaeogeography, Palaeoclimatology, Palaeoecology 274(1-2):105-113.

De Francesco, C. G. \& Isla, F. I. 2004. Reproductive period and growth rate of the fresh-water snail Heleobia parchappii (d'Orbigny, 1835) (Gastropoda: Rissooidea) in a shallow brackish habitat (Buenos Aires Province, Argentina). Malacologia 45:443-450.

Falniowski, A. \& Szarowska, M. 2000. A new species of Daphniola Radoman, 1973 (Gastropoda: Hydrobiidae) from Greece. Folia Malacologica 8:181-188.

Felsenstein, J. 1985. Confidence limits on phylogenies: An approach using the bootstrap. Evolution 39:783-791.

Folmer, O.; Back, M.; Hoen, W.; Lutz, R. \& VRiJenhoek, R. 1994. DNA primers for amplification of mitochondrial cytochrome $\mathrm{C}$ oxidase subunit I from diverse metazoan invertebrates. Molecular Marine Biology and Biotechnology 3:294-299.

Gaillard, M. C. \& De Castellanos, Z. A. 1976. Mollusca, Gasteropoda, Hydrobiidae. In: Ringuelet, R. A. ed. Fauna de agua dulce de la República Argentina, 15(2). Buenos Aires, Fundación para la Educación, la Ciencia y la Cultura (FECIC), p. 1-39.
Utierrez Gregoric, D. E.; Ciocco, N. F. \& Rumi, A. 2014. Two new species of Chilina Gray from Cuyo Malacological Province, Argentina (Gastropoda: Hygrophila: Chilinidae). Molluscan Research 34(2):8497.

HaLl, T. A. 1999. BioEdit: a user-friendly biological sequence alignment editor and analysis program for Windows 95/98/NT. Nucleic Acids Symposium Series 41:95-98.

Hershler, R.; Mulvey, M. \& Liu, H. P. 1999. Biogeography in the Death Valley region: evidence from spring snails (Hydrobiidae: Tryonia). Zoological Journal of the Linnean Society 126(3):335-354.

Hershler, R. \& Thompson, F. G. 1992. A review of the aquatic gastropod subfamily Cochliopinae (Prosobranchia: Hydrobiidae). Malacological Review 5:1-140.

Kabat, A. R. \& Hershler, R. 1993. The prosobranch snail family Hydrobiidae (Gastropoda: Rissooidea): review of classification and supraspecific taxa. Smithsonian Contributions to Zoology 547:1-94.

Kroll, O.; Hershler, R.; Albrecht, C.; Terrazas, E. M.; Apaza, R.; Fuentealba, C. \& Wilke, T. 2012. The endemic gastropod fauna of Lake Titicaca: correlation between molecular evolution and hydrographic history. Ecology and Evolution 2(7):1517-1530.

Liu, H. P.; Hershler, R. \& Thompson, F. G. 2001. Phylogenetic relationships of the Cochliopinae (Rissooidea: Hydrobiidae): an enigmatic group of aquatic gastropods. Molecular Phylogenetics and Evolution 21:17-25.

López Armegol, M. F. 1996. Taxonomic revision of Potamolithus agapetus (Pilsbry, 1911) and Potamolithus buschii (Frauenfeld, 1865) (Gastropoda: Hydrobiidae). Malacologia 38(1/2):1-17.

Marcus, E. \& Marcus, E. 1963. Mesogastropoden von der Küste São Paulos. Abhandlungen der Mathematisch-Naturwissenschaftlichen Klasse. Akademie der Wissenschaften und der Literatur in Mainz 1:32-105.

1965. On Brazilian supra- tidal and estuarine snails. Boletim da Faculdade de Filosofia, Ciências e Letras da Universidade de São Paulo, Zoologia 25:18-103.

Martín, P. R. 2002. Evidence for parthenogenesis and natural imposex in the Patagonian freshwater snail Heleobia hatcheri (Gastropoda: Hydrobiidae). Journal of Molluscan Studies 68:291-295.

Neves, R. A. F.; Valentin, J. L. \& Figueiredo, G. M. 2010. Morphological description of the gastropod Heleobia australis (Hydrobiidae) from egg to hatching. Brazilian Journal of Oceanography 58(3):247-250.

NúÑez, V.; Gutierrez Gregoric, D. E. \& Rumi A. 2010. Freshwater gastropod provinces from Argentina. Malacologia 53:47-60.

Rumi, A.; Gutiérrez Gregoric, D. E.; NúÑez, V. \& Darrigran, G. A. 2008. Malacología latinoamericana. Moluscos de agua dulce de Argentina. Revista de Biología Tropical 56:77-111.

TAmura, K. \& Nei, M. 1993. Estimation of the number of nucleotide substitutions in the control region of mitochondrial DNA in humans and chimpanzees. Molecular Biology and Evolution 10:512-526.

Tamura, K.; Stecher, G.; Peterson, D.; Filipski, A. \& Kumar, S. 2013. MEGA6: Molecular Evolutionary Genetics Analysis version 6.0. Molecular Biology and Evolution 30:2725-2729.

Wilke, T.; Davis, G. M; Falniowski, A.; Giusti, F.; Bodon, M. \& Szarowska, M. 2001. Molecular systematics of Hydrobiidae (Mollusca: Gastropoda: Rissooidea): testing monophyly and phylogenetic relationships. Proceedings of the Academy of Natural Sciences of Philadelphia 151:1-21.

Wilke, T.; Haase, M.; Hershler, R.; Liu, H. P.; Misof, B. \& Ponder, W. 2013. Pushing short DNA fragments to the limit: phylogenetic relationships of 'hydrobioid' gastropods (Caenogastropoda: Rissooidea). Molecular Phylogenetics and Evolution 66(3):715736 .

Wilke, T.; Rolán, E. \& Davis, G. M. 2000. The mudsnail genus Hydrobia ss in the northern Atlantic and western Mediterranean: a phylogenetic hypothesis. Marine Biology 137(5-6):827-833. 